\title{
Biochemical characteristics and bacterial community structure of the sea surface microlayer in the South Pacific Ocean
}

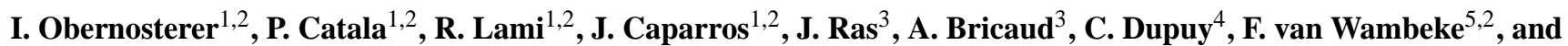 \\ P. Lebaron ${ }^{1,2}$ \\ ${ }^{1}$ Université Pierre et Marie Curie-Paris6, UMR7621; F66650 Banyuls-sur-Mer, France \\ ${ }^{2}$ CNRS, UMR7621, F-66650 Banyuls-sur-Mer, France \\ ${ }^{3}$ CNRS, Laboratoire d'Océanographie de Villefranche, 06230 Villefranche sur Mer, France; Université Pierre et Marie \\ Curie-Paris6, Laboratoire d'Océanographie de Villefranche, 06230 Villefranche sur Mer, France \\ ${ }^{4}$ Université de la Rochelle, Pôle Science, CRELA, UMR6217, Av. Michel Crépeau, 17042 La Rochelle cedex 01, France \\ ${ }^{5}$ Laboratoire de Microbiologie, Géologie et Ecologie Marine (LMGEM), CNRS 6117, Université de la Méditerranée, Campus \\ de Luminy - Case 901, 13288 Marseille cedex 9, France
}

Received: 10 July 2007 - Published in Biogeosciences Discuss.: 22 August 2007

Revised: 23 April 2008 - Accepted: 23 April 2008 - Published: 6 May 2008

\begin{abstract}
The chemical and biological characteristics of the surface microlayer were determined during a transect across the South Pacific Ocean in October-December 2004. Concentrations of particulate organic carbon (1.3 to 7.6-fold) and nitrogen (1.4 to 7 -fold), and POC:PON ratios were consistently higher in the surface microlayer as compared to surface waters $(5 \mathrm{~m})$. The large variability in particulate organic matter enrichment was negatively correlated to wind speed. No enhanced concentrations of dissolved organic carbon were detectable in the surface microlayer as compared to $5 \mathrm{~m}$, but chromophoric dissolved organic matter was markedly enriched (by 2 to 4 -fold) at all sites. Based on pigment analysis and cell counts, no consistent enrichment of any of the major components of the autotrophic and heterotrophic microbial community was detectable. CE-SSCP fingerprints and CARD FISH revealed that the bacterial communities present in the surface microlayer had close similarity $(>76 \%)$ to those in surface waters. By contrast, bacterial heterotrophic production $\left({ }^{3} \mathrm{H}\right.$-leucine incorporation) was consistently lower in the surface microlayer than in surface waters. By applying CARD-FISH and microautoradiography, we observed that Bacteroidetes and Gammaproteobacteria dominated leucine uptake in the surface microlayer, while in surface waters Bacteroidetes and Alphaproteobacteria were the major groups accounting for leucine incorporation. Our results demonstrate that the microbial community in the surface microlayer closely resembles that of the surface
\end{abstract}

Correspondence to: I. Obernosterer (ingrid.obernosterer@obs-banyuls.fr) waters of the open ocean. Even a short residence in the surface microlayer influences leucine incorporation by different bacterial groups, probably as a response to the differences in the physical and chemical nature of the two layers.

\section{Introduction}

The air-water interface is a site of dynamic exchange processes of gaseous, liquid and particulate matter between the atmosphere and aquatic environments (Liss et al., 1997). The atmospheric-aquatic boundary layer, comprised of a series of sub-layers that are generally summarized as the sea surface microlayer $(1-1000 \mu \mathrm{m})$, plays a pivotal role in these transfer processes. The enrichment of the surface microlayer in organic and inorganic matter affects physical features of the air-sea interface such as the surface tension, and thus air-sea fluxes (Frew, 1997). The potential contribution of biological activity in the surface microlayer to air-water exchange processes is far less known. The partial pressure of $\mathrm{CO}_{2}$ in the top layer $(2 \mathrm{~cm})$ of the ocean was recently reported to be linked to microbial community metabolism (Calleja et al., 2005). The consistently enhanced rates of respiration in samples collected from the surface microlayer in different coastal and offshore marine environments support this notion (Garabétian, 1990; Obernosterer et al., 2005; Reinthaler et al., 2008). The biogenic gases dimethylsulfoxide (DMSO) and dimethylsulfoniopropionate (DMSP) were markedly enriched in the surface microlayer as compared to surface waters during calm wind conditions (Zemmelink et al., 2005). These observations could indicate that important biological

Published by Copernicus Publications on behalf of the European Geosciences Union. 


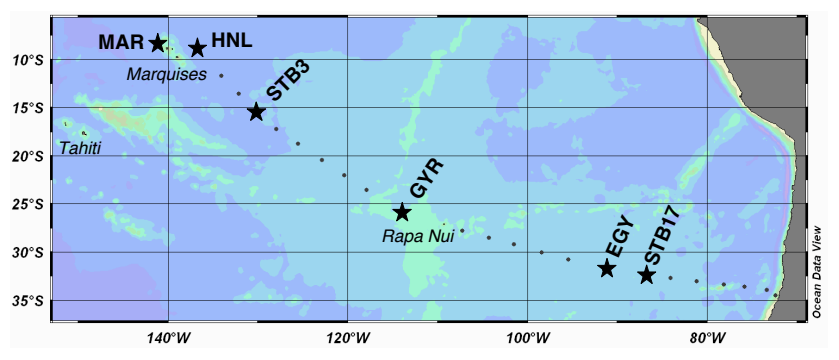

Fig. 1. Cruise track and sampled stations of the BIOSOPE (BIogeochemistry and Optics South Pacific Ocean Experiment) project. Stations where the sea surface microlayer was collected are indicated by stars.

processes at the air-water interface differ from those in surface waters, however, their impact on air-sea fluxes remains to be determined.

Whether organisms inhabiting the surface microlayer act as sources or sinks for various components will strongly depend on the abundance and activity of the different members of the microbial community. Reports on these biological features display large variability among studies, with enrichments, depletions or no differences observed (Agogué et al., 2004 and references therein). This is most likely due to the spatial and temporal variability in the development of the surface microlayer. The utilization of different sampling devices that collect layers of varying thickness could also account for the differences observed. Another important issue to be addressed is the specificity of the autotrophic and heterotrophic community inhabiting the surface microlayer. Phytoneuston has long been viewed as a unique group of organisms inhabiting the surface film of aquatic environments (see review by Zaitsev, 1997), but this idea has recently been challenged. Based on the tight relationship between the abundance of different groups of the plankton community in surface waters and that in the surface microlayer, the upward transport of organisms by physical processes rather than the in situ development has been suggested the source for their presence in the surface microlayer (Joux et al., 2006).

Only recently have molecular tools allowed to address the question whether heterotrophic bacteria inhabiting the surface microlayer display a specific community structure. The only two studies available up to date reveal contrasting conclusions (Agogué et al., 2004; Franklin et al., 2005). Based on different sampling techniques and molecular approaches, the bacterial community structure associated with the surface microlayer was found to be similar in the coastal Mediterranean Sea (Agogué et al., 2004) or distinctly different in the North Sea (Franklin et al., 2005) to that from surface waters.

The objective of the present study was to evaluate by two complementary molecular-based techniques whether the top layer of the ocean is inhabited by a distinct bacterioneuston community. Our aim was to describe the bacterial community structure in relation to major biological and chemical features that characterized the surface microlayer in contrasting marine environments across the South Pacific Ocean.

\section{Material and methods}

\subsection{Study sites}

The BIOSOPE (BIogeochemistry and Optics South Pacific Experiment) cruise track crossed the South Pacific Ocean from the Marquise Islands to Chile (Claustre et al., 2008 ${ }^{1}$ ). The surface microlayer was sampled at 6 stations ranging from oligotrophic to ultraoligotrophic in the center of the South Pacific Gyre (Fig. 1). The sampled sites were located in the vicinity of the Marquise Islands (Station MAR), in High-Nutrient-Low-Chlorophyll waters east of the Marquise Islands (Station HNL), in the center of the South Pacific Gyre (Station GYR), in the eastern part of the South Pacific Gyre (Station EGY), and in the western (STB3) and eastern (STB17) part of the South Pacific Ocean (Fig. 1, Table 1). Wind speed was recorded every $10 \mathrm{~s}$. Sea surface microlayer collection was done during calm wind conditions $\left(<3 \mathrm{~m} \mathrm{~s}^{-1}\right)$ and the mean wind speed $6 \mathrm{~h}$ prior to sampling varied between 0.5 and $2.6 \mathrm{~m} \mathrm{~s}^{-1}$ at the different stations.

\subsection{Surface microlayer sampling}

We used a metal screen (Garrett, 1965) to collect the surface microlayer (250-400 $\mu \mathrm{m}$ ) as described previously (Obernosterer et al., 2005). Sampling was done from a dinghy, roughly 0.5 nautical miles upwind from the research vessel. To prevent the collection of water adhering to the frame, the first $100 \mathrm{ml}$ of water draining from the metal screen were rejected. Prior to collection, the metal screen was rinsed several times with the respective sample water. Surface water was collected at $5 \mathrm{~m}$ using a 5-1 Niskin bottle. Samples collected in the surface microlayer and in surface waters were transferred to 9-1 polycarbonate (PC) carboys. Prior to sampling, the PC carboys were rinsed with $1 \mathrm{~N} \mathrm{HCl}$, Milli-Q water and 3 times with the respective water samples.

\subsection{Particulate organic carbon (POC) and nitrogen (PON) and dissolved organic carbon (DOC)}

For POC-analysis, duplicate 700-1000-ml samples were filtered onto combusted $\left(450^{\circ} \mathrm{C}\right.$ for $5 \mathrm{~h}$ ) Whatman $\mathrm{GF} / \mathrm{F}$ filters. The filters were rinsed with $\sim 2 \mathrm{ml}$ of Milli-Q water to remove salts, then stored frozen $\left(-20^{\circ} \mathrm{C}\right)$ until analysis. POC and PON measurements were performed on a 2400 Perkin Elmer CHN analyzer. The error for duplicate samples of POC and PON was, on average, $4 \%$ and $12 \%$, respectively.

\footnotetext{
${ }^{1}$ Claustre, H., Sciandra, A., and Vaulot, D.: Introduction to the special section: bio-optical and biogeochemical conditions in the South East Pacific in late 2004 - the BIOSOPE cruise, submittedto Biogeosciences Discuss., 2008.
} 
Table 1. Date and local time of the day of the surface microlayer collection and general characteristics of the study sites. Phytoplankton biomass (chl- $a$ ) is integrated over the euphotic zone. Mean wind speed for $6 \mathrm{~h}$ prior to the surface microlayer collection is given. Ze - depth of the euphotic zone.

\begin{tabular}{|c|c|c|c|c|c|}
\hline Station & Date & Time of the Day & $\mathrm{Ze}(\mathrm{m})$ & $\operatorname{chl}-a\left(\mathrm{mg} \mathrm{m}^{-2}\right)^{1}$ & Wind speed $\left(\mathrm{m} \mathrm{s}^{-1}\right)$ \\
\hline MAR & 29 Oct. 2004 & 10:00-11:00 & 78 & 21 & 2.6 \\
\hline HNL & 1 Nov. 2004 & $13: 30-14: 30$ & 90 & 17 & 2.6 \\
\hline STB3 & 5 Nov. 2004 & $15: 00-16: 00$ & 134 & 16 & 1.9 \\
\hline GYR-2 & 12 Nov. 2004 & $12: 00-13: 00$ & 160 & 11 & 1.9 \\
\hline GYR-4 & 14 Nov. 2004 & $13: 30-14: 30$ & 142 & 7 & 2.0 \\
\hline EGY & 28 Nov. 2004 & 09:00-10:30 & 94 & 15 & 0.5 \\
\hline STB17 & 1 Dec. 2004 & $13: 30-14: 30$ & 96 & 15 & 1.4 \\
\hline
\end{tabular}

${ }^{1}$ Data are from Ras et al. (2008)

For DOC-analysis, GF/F filtered samples were preserved by adding $100 \mu 1 \mathrm{H}_{3} \mathrm{PO}_{4}$ (35\%) to $20 \mathrm{ml}$ subsamples. The samples were stored in combusted glass vials with Teflonlined screw caps in the dark at $4^{\circ} \mathrm{C}$ until analyzed. DOC measurements were performed on a Shimadzu TOC-V-CSH (Benner and Strom, 1993). Prior to injection, DOC samples were sparged with $\mathrm{CO}_{2}$-free air for 6 min to remove inorganic carbon. Hundred $\mu 1$ of sample were injected in triplicate and the analytical precision was $\sim 2 \%$. Standards were prepared with acetanilid. The error for duplicate DOC samples was, on average, $1 \%$.

\subsection{Chromophoric Dissolved Organic Matter (cDOM)}

The absorption coefficients of cDOM were measured throughout the ultraviolet-visible domain $(280-735 \mathrm{~nm})$ using the multiple path length, liquid core waveguide system UltraPath (WPI Inc.), with a pathlength of $2 \mathrm{~m}$. Samples were filtered immediately after collection, in dim light, using $0.2 \mu \mathrm{m}$ Millipore filters pre-rinsed with Milli-Q water. Filtered samples were then placed in the automatic sampler (maintained in the dark), and pumped into the sample cell of the Ultrapath instrument. Absorbance spectra were measured with reference to a salt solution (35 PSU), prepared with High Pressure Liquid Chromatographie (HPLC)quality water and granular $\mathrm{NaCl}$, to match the salinity and refractive index of samples. Between measurements, the cell was flushed successively with diluted detergent, high reagent grade $\mathrm{MeOH}, 2 \mathrm{M} \mathrm{HCl}$, and Milli-Q water, and the cleanliness of the tube was controlled using a reference value for the transmittance of the reference water. As the absorption coefficients of pure water vary with temperature (especially in the infra-red), we minimized the temperature differences between the reference and the sample. The presence of microbubbles in the sample cell was also avoided by using a peristaltic pump and a debubbler.

\subsection{Pigment analysis}

Three to six liters of seawater were filtered onto GF/F filters $(25 \mathrm{~mm}$ diameter) and the filters were stored in liquid nitrogen until HPLC-analysis according to Van Heukelem and Thomas (2001). A detailed description of the pigment extraction and analysis is given in Ras et al. (2008).

2.6 Enumeration of heterotrophic bacteria, autotrophic prokaryotic and eukaryotic cells by flow cytometry

Three-ml subsamples were fixed with $2 \%$ formaldehyde (final conc.), stored for $30 \mathrm{~min}$ at $4^{\circ} \mathrm{C}$, then frozen in liquid nitrogen and stored at $-80^{\circ} \mathrm{C}$ until analysis. For flow cytometric analysis of heterotrophic bacteria, samples were stained with the nucleic acid dye SYBR Green-I (Molecular Probes) at $0.025 \%$ (vol/vol) final concentration (Lebaron et al., 2001). Counts were performed on a FACS-Calibur flow cytometer (Becton Dickinson, San Jose, CA) equipped with a $488 \mathrm{~nm}$ wavelength, $15 \mathrm{~mW}$ Argon laser. Stained bacteria were excited at $488 \mathrm{~nm}$ wavelength and discriminated according to their right angle-light scatter (SSC, related to cell size) and green fluorescence at $530 \pm 15 \mathrm{~nm}$ wavelength. Based on a plot of green versus red fluorescence we distinguished photosynthetic from non-photosynthetic prokayotes. Enumeration of autotrophic cells was performed according to Marie et al. (2000). Synechococcus spp. was discriminated by its strong orange fluorescence $(585 \pm 21 \mathrm{~nm})$ and pico- and nanoeukaryotes were discriminated by their scatter signals of the red fluorescence $(>670 \mathrm{~nm})$. The coefficient of variation among replicate samples is generally $<5 \%$ (Agogué et al., 2004). To convert bacterial abundance to bacterial biomass we applied a conversion factor of $12.4 \mathrm{fg} \mathrm{C}_{\mathrm{g}} \mathrm{Cel}^{-1}$ (Fukuda et al., 1998).

\subsection{Enumeration of nanoflagellates}

Plastidic and heterotrophic nanoflagellates were determined after staining with Primulin according to Sherr et al. (1993). 
Twenty to one hundred $\mathrm{ml}$ of raw seawater were fixed with $2 \%$ formaldehyde (final conc.) and filtered onto $0.8 \mu \mathrm{m}$ black PC membrane filters ( $25 \mathrm{~mm}$ filter diameter). The filter was subsequently rinsed with two $1-\mathrm{ml}$ aliquots of $0.1 \mathrm{M}$ Trizma $\mathrm{HCl}(\mathrm{pH} 4.0)$. The filter was covered with Primulin $\left(250 \mathrm{~g} \mathrm{ml}^{-1}, 0.1 \mathrm{M}\right.$ Trizma-HCl$)$ and incubated in the dark for $15 \mathrm{~min}$. After removing the Primulin solution by filtration, the filter was rinsed again with $0.1 \mathrm{M}$ Trizma $\mathrm{HCl}$, before being mounted onto a glass slide. Heterotrophic and autotrophic nanoflagellates were subsequently visualized using UV and blue light excitation, respectively, using an epifluorescence microscope (x 1000, Zeiss, Axiovert Mot plus).

\subsection{Bacterial heterotrophic production}

Bacterial production was determined by $\left[{ }^{3} \mathrm{H}\right]$ leucine incorporation applying the centrifugation method (Smith and Azam 1992). Briefly, $1.5 \mathrm{ml}$ samples were incubated with a mixture of $\left[4,5-{ }^{3} \mathrm{H}\right]$ leucine (Amersham, specific activity $160 \mathrm{Ci} \mathrm{mmol}^{-1}$ ) and nonradioactive leucine at final concentrations of 7 and $13 \mathrm{nM}$, respectively. Samples were incubated in the dark at the respective in situ temperatures for $2-3 \mathrm{~h}$. Linearity of leucine incorporation over this time period was tested at the three stations. Incubations were terminated by the addition of trichloracetic acid (TCA, Sigma) to a final concentration of $5 \%$. To facilitate the precipitation of proteins, bovine serum albumine (BSA, Sigma, $100 \mathrm{mg}$ $1^{-1}$ final concentration) was added prior to centrifugation at $16000 \mathrm{~g}$ for $10 \mathrm{~min}$ (Van Wambeke et al., 2002). After discarding the supernatant, $1.5 \mathrm{ml}$ of $5 \%$ TCA were added and the samples were subsequently vigorously shaken on a vortex and centrifuged again. The supernatant was discarded, $1.5 \mathrm{ml}$ of PCS liquid scintillation cocktail (Amersham) added and the radioactivity incorporated into bacterial cells was counted aboard with a Packard LS 1600 Liquid Scintillation Counter. The variation between two replicate measurements was on average $\pm 10 \%$ from the mean.

2.9 Catalyzed reporter deposition - fluorescence in situ hybridization and microautoradiography (MICROCARD-FISH)

At three stations (MAR, GYR and STB17) the bacterial community structure and the activity of the major bacterial groups was determined applying MICRO-CARD-FISH. Raw seawater samples $(50 \mathrm{ml})$ were incubated with [4,5${ }^{3} \mathrm{H}$ ]leucine (Amersham, specific activity $160 \mathrm{Ci} \mathrm{mmol}^{-1}$ ) at a final concentration of $20 \mathrm{nM}$ in the dark at in situ temperature for $2-4 \mathrm{~h}$. The incubation was terminated by adding paraformaldehyde (PFA, 2\% final concentration), and controls were fixed with PFA ( $2 \%$ final concentration) prior to incubation with ${ }^{3} \mathrm{H}$-leucine. Samples were stored at $4{ }^{\circ} \mathrm{C}$ in the dark for $12 \mathrm{~h}$ before filtration onto $0.2 \mu \mathrm{m}$ PC filters ( $25 \mathrm{~mm}$ filter diameter, Nuclepore). The filters were stored at $-20^{\circ} \mathrm{C}$ until treated by CARD-FISH using the protocols described in Pernthaler et al. (2002) and Sekar et al. (2003). Filters were embedded in low-melting-point agaraose $(0.2 \%$ final concentration), dried, dehydrated (96\% EtOH, $1 \mathrm{~min})$ and treated with lysozyme (Fluka, $10 \mathrm{mg} \mathrm{ml}^{-1}, 100 \mathrm{mM}$ Tris [pH 8], $50 \mathrm{mM}$ EDTA) for $1 \mathrm{~h}$ at $37^{\circ} \mathrm{C}$ to allow cell wall permeabilization. The filters were subsequently washed in Milli-Q water and dehydrated in ethanol (96\%) for $1 \mathrm{~min}$.

We determined the relative contribution of the major bacterial groups using the probes ALF968 (5'-GGT AAG GTT CTG CGC GTT-3') for Alphaproteobacteria, GAM42a (5'GCC TTC CCA CAT CGT TT-3') for Gammaproteobacteria, and CFB319a (5'-TGG TCC GTG TCT CAG TAC-3') for Bacteroidetes, and a mix of the the probes EUB338I (5'GCT GCC TCC CGT AGG AGT-3'), EUB338II (5'-GCA GCC ACC CGT AGG TGT-3') and EUB338III (5'-GCT GCC ACC CGT AGG TGT-3') for the identification of Bacteria. The negative control (NON338, 5'-ACT CCT ACG GGA GGC AGC-3') was used to determine non-specific binding. Probe working solution was added at a final con-

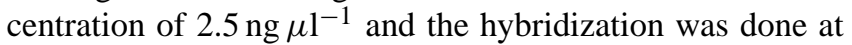
$35^{\circ} \mathrm{C}$ for $2 \mathrm{~h}$.

For the microautoradiographic development, we followed the protocol described by Cottrell and Kirchman (2000). Briefly, the previously hybridized filter sections were placed onto slides coated with photographic emulsion (type NTB-2; Kodak, diluted 1:1 with Milli-Q water). The photographic emulsion was heated at $43^{\circ} \mathrm{C}$ for $30-60$ min before utilization. The slides were then dried (for $15 \mathrm{~min}$ ) on an ice-cold aluminum plate and kept in a dark box during exposure at $4^{\circ} \mathrm{C}$. The slides were developed for $2 \mathrm{~min}$ (Dektol developer [1:1 dilution with Milli-Q water], Kodak), rinsed with Milli$\mathrm{Q}$ water for $10 \mathrm{~s}$, fixed for 6 min (Fixer Tmax, Kodak) and again rinsed for 6 min in Milli-Q water. After having dried the slides in a desiccator for $12 \mathrm{~h}$, filter sections were peeled off and the cells were counterstained with a DAPI mix (4 parts Citifluor, 1 part Vectashield (Vector Laboratories) with DAPI at a final concentration of $0.5 \mu \mathrm{g} \mathrm{ml}^{-1}$ ). To determine the appropriate exposure time for samples collected in the surface microlayer and surface waters, slides were developed after 12 h, 24 h, 36 h, 48 h, $72 \mathrm{~h}$ and $96 \mathrm{~h}$ at Stations GYR and STB17. At both stations, the percent of DAPI-stained cells associated with silver grains increased during the first $48 \mathrm{~h}$ and remained stable thereafter. We subsequently used an exposure time of $48 \mathrm{~h}$. The slides were examined under a Olympus AX70 epifluorescence microscope and an image analysis system as described in Cottrell and Kirchman (2003). For each slide, 20 fields were enumerated, resulting in a minimum of 500 DAPI-stained cell counts. Mean values and the standard errors among the cell counts of 20 fields are presented. To determine the contribution of different bacterial groups to leucine incorporation, the number of probe-positive cells associated with silver grains was divided by the number of DAPI-stained cells associated with silver grains. 
2.10 Capillary electrophoresis - single strand conformation polymorphism (CE-SSCP)

At all stations CE-SSCP was performed on DNA extracts to obtain molecular fingerprints of the surface microlayer and surface waters. Seawater samples $(<3 \mu \mathrm{m}$ size fraction, $0.5 \mathrm{l})$ were filtered onto $0.2 \mu \mathrm{m}$ PC filters $(47 \mathrm{~mm}, \mathrm{Nu}-$ clepore) and filters were kept frozen $\left(-80^{\circ} \mathrm{C}\right)$ until nucleic acid extraction. Nucleic Acid extraction was performed as described previously (Ghiglione et al., 2005). Primers used for polymeric chain reaction (PCR) were the specific bacterial primers w49dir (5' -A CGG TCC AGA CTC CTA CGG G-3'; Delbès et al., 2000) and w34rev (5' -TTA CCG CGG CTG CTG GCA C- 3'; Lee et al., 1996) synthesized commercially (Eurogentec). Primer w34 was fluorescently 5'labelled with phosphoramidite (TET, Eurogentec). Primers were designed to target a short sequence (around $200 \mathrm{pb}$ ), allowing a good resolution of the CE-SSCP signal (V3 region of 16SrDNA, Escherichia coli positions 329-533, .Brosius et al., 1981). Amplifications were performed in $50 \mu 1$, with $1 \mu \mathrm{l}$ of DNA, $0.3 \mu \mathrm{M}$ of each primer, $0.8 \mathrm{mM}$ dNTPs, and $1 \mathrm{X}$ buffer (Promega), before adding $1.0 \mathrm{U}$ of $p f u$ polymerase (Promega). Samples were amplified (Robocycler 96, Stratagene) with the following program : $94^{\circ} \mathrm{C}(3 \mathrm{~min})$ for denaturation, 25 cycles at $94^{\circ} \mathrm{C}$ (denaturation, $30 \mathrm{~s}$ ), $61^{\circ} \mathrm{C}$ (annealing, $25 \mathrm{~s}$ ), $72^{\circ} \mathrm{C}$ (extension, $30 \mathrm{~s}$ ), before a final extension at $72^{\circ} \mathrm{C}(10 \mathrm{~min})$. The amplicon size was checked on agarose gel (2\%), and the PCR products were purified using a PCR purification kit (Qiagen).

\subsubsection{CE-SSCP electrophoresis}

CE-SSCP was performed according to a previously described protocol (Ghiglione et al., 2005) on the Genetic Analyser ABI310 (Applied Biosystems). Briefly, each sample was diluted between 2- and 40-fold in sterile Tris-borate-EDTA (TBE)(10 mM Tris, $1 \mathrm{mM}$ EDTA) to obtain $10 \mathrm{ng} \mu \mathrm{l}^{-1}$ of PCR product. From this resulting dilution, $1 \mu \mathrm{l}$ of PCR product was mixed with $0.1 \mu \mathrm{l}$ of an internal size standard (GeneScan-400 Rox, Applied Biosystems) and $18.9 \mu 1$ of deionised formamide (Applera), before heating $\left(94^{\circ} \mathrm{C}\right.$, $10 \mathrm{~min})$ and cooling in a water/ice bath $(10 \mathrm{~min})$. Samples were electrokinetically injected $(5 \mathrm{~s}, 12 \mathrm{kV})$ into a capillary $(47 \mathrm{~cm} \times 50 \mu \mathrm{m})$ filled with $5.6 \%$ GeneScan polymer (Applied Biosystems) gel containing $10 \%$ autoclaved glycerol in sterile TBE buffer ( $90 \mathrm{mM}$ Tris-borate, $2 \mathrm{mM}$ EDTA [pH 8.0]). Samples migrated for $30 \mathrm{~min}\left(15 \mathrm{kV}, 30^{\circ} \mathrm{C}\right)$. Phosphoramidite (TET)-labelled fragments were detected by a laser with a virtual filter $C$ (detection wavelengths 532, 537 and $584 \mathrm{~nm}$ ). Data collection was performed with the ABI Prism 310 collection software (Applied Biosystems).

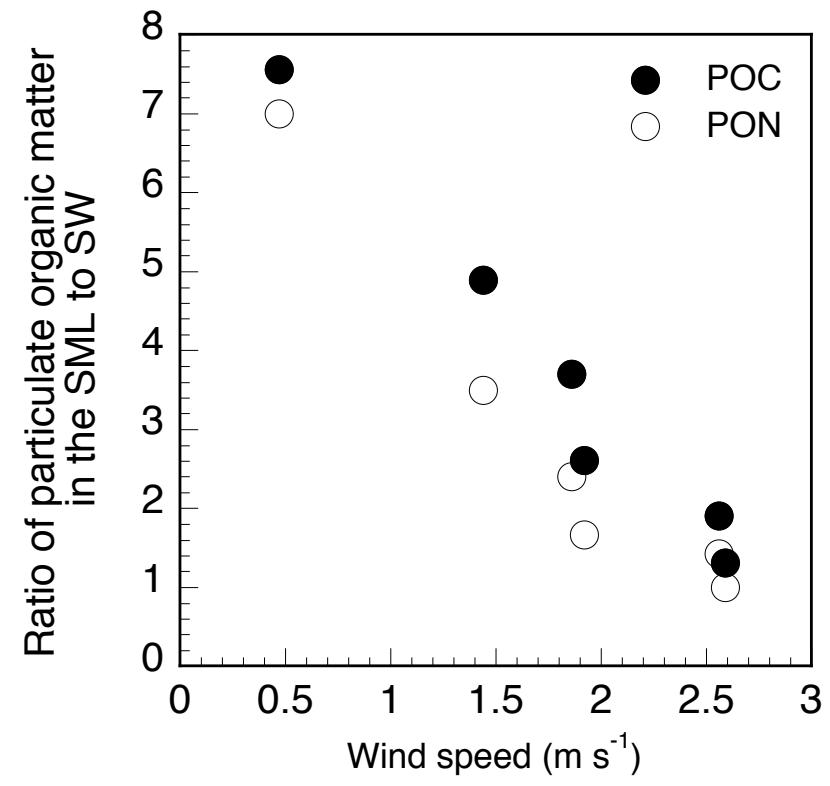

Fig. 2. Relation between the ratio of particulate organic carbon (POC) and nitrogen (PON) in the surface microlayer (SML) to that in surface waters $(\mathrm{SW})$ and the mean wind speed $6 \mathrm{~h}$ prior to sampling.

\subsubsection{CE-SSCP fingerprints analysis}

Electrophoregrams were aligned with the GeneScan analysis software by fixing positions of the internal standard (GeneScan-400 Rox, Applied Biosystems) with a secondorder least-square curve (i.e. linear regression). Peak detection on environmental fingerprints was realized using the first derivative of a polynomial curve fitted to the data within a window that was centred on each data point (GeneScan analysis software). Peaks overlapping were observable on the obtained fingerprints, to avoid artefacts in peak enumeration we used a high polynomial degree (10) to increase peak sensitivity. The peak amplitude threshold was fixed at 50 and applied for both Rox and TET fluorescent dyes.

\section{Results}

\subsection{Particulate and dissolved organic matter}

The surface microlayer was markedly enriched in particulate organic matter, by factors varying between 1.3 and 7.6 for POC, and between 1.4 and 7 for PON (Table 2). The variability in particulate organic matter enrichment was largely explained by wind history. The ratio of POC in the surface microlayer to that of surface waters (i.e. the enrichment factor) was negatively correlated to the mean wind speed $6 \mathrm{~h}$ prior to sampling $\left(r^{2}=0.97, n=6, p<0.0001\right.$, Fig. 2). This was also the case for the PON enrichment factor $\left(r^{2}=0.93\right.$, $n=6, p=0.0004)$. No relationship between the concentration 

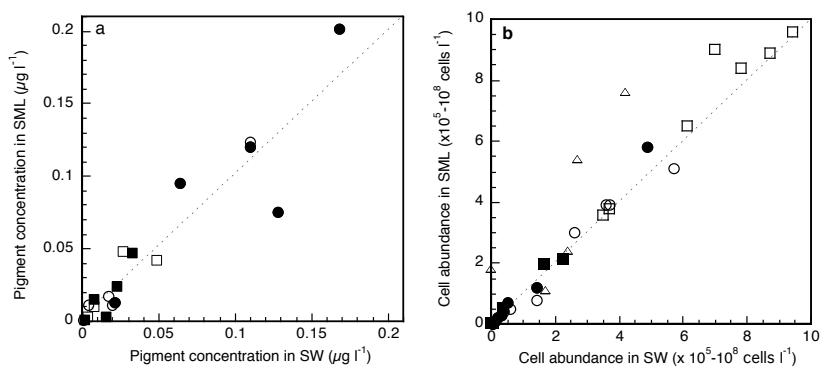

Fig. 3. Relation between (a) pigment concentration and (b) the abundance of autotrophic and heterotrophic cells in the surface microlayer (SML) and in surface waters (SW). Data of all pigment analyses and all cell counts are pooled. (a) filled circles: chl- $a$; empty circles: chl- $b$; filled squares: chl- $c$; empty squares: Divinyl chl- $a$. (b) filled circles: Synechococcus spp. $\left(\times 10^{7} 1^{-1}\right)$; empty circles: Pico/Nanoeukaryotes $\left(\times 10^{6} 1^{-1}\right)$; filled squares: Plastidic Nanoflagellates $\left(\times 10^{6} 1^{-1}\right)$; empty squares: Heterotrophic bacteria $\left(\times 10^{8} 1^{-1}\right)$; empty triangles: Heterotrophic nanoflagellates $\left(\times 10^{5} 1^{-1}\right)$. Dashed line indicates the 1:1 line.

of particulate organic matter in the surface microlayer and in surface waters was detectable. $\mathrm{C} / \mathrm{N}$ ratios of particulate organic matter were by 1.1 to 1.6 -fold higher in the surface microlayer than at $5 \mathrm{~m}$, indicating preferential accumulation of carbon-rich organic matter. Concentrations of dissolved organic carbon did not display any particulate pattern (Table 2). By contrast, cDOM was enriched in the surface microlayer by 2-fold at Stations MAR, HNL, STB3 and GYR, and by 4 -fold at Station EGY (Table 2).

3.2 Autotrophic and heterotrophic components of the sea surface microlayer

The components of the microbial community determined in the present study did not exhibit any consistent pattern in terms of biomass or abundance in the surface microlayer as compared to surface waters (Fig. 3). Concentrations of chlorophyll- $a$ in the surface microlayer exceeded those at $5 \mathrm{~m}$ at Stations MAR and EGY by factors of 1.2 and 1.5, respectively. At Stations HNL, GYR and STB17 concentrations of chlorophyll- $a$ in the surface microlayer were similar or depleted compared to those at $5 \mathrm{~m}$ (Table 3). The group specific pigments chlorophyll- $b$ (Chlorophytes) and chlorophyll- $c$ (Chromophytes) revealed a similar trend as chlorophyll- $a$ with pronounced enrichments only at Station EGY (by 2.8- and 1.9-fold, respectively). Concentrations of divinyl chlorophyll-aindicated an enrichment of Prochlorococcus in the surface microlayer at Stations MAR (by 1.8fold) and EGY (by 1.3-fold), similar to that of Synechococcus based on cell abundances (by 1.2- and 1.4-fold, respectively) (Tables 3 and 4). Pico- and nanoeukaryotes displayed similar abundances in the surface microlayer and in surface waters. Plastidic and heterotrophic nanoflagellates were more abundant (by 1.2- to 4-fold) in the surface microlayer

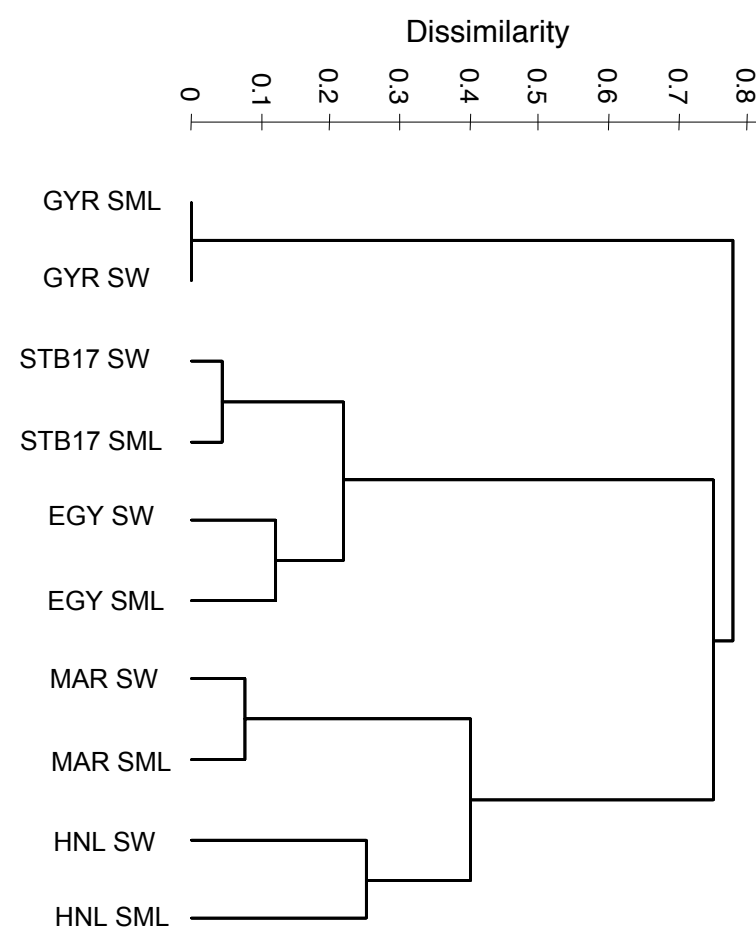

Fig. 4. UPGMA dendrogram generated from the CE-SSCP profiles from the surface microlayer (SML) and surface waters (SW). Scale bar indicates the dissimilarity.

in 3 out of 5 surface microlayer samplings. Phaeopigments were below the limit of detection in the surface microlayer and in surface waters of all stations. No marked enrichment of heterotrophic bacterial abundances was detectable in the surface microlayer (mean 1.04, range 1.01-1.08), except for Station EGY where abundances exceeded those at $5 \mathrm{~m}$ by 1.3-fold (Table 4).

\subsection{Bacterial community structure}

The CE-SSCP fingerprints revealed overall close similarity $(>76 \%)$ of the bacterial community structure between the surface microlayer and surface waters (Fig. 4). The UPGMA dendrogram is based on the comparison of the presence or absence of peaks (thereafter referred to as ribotype) among the CE-SSCP fingerprints. The number of peaks represented on the fingerprints ranged between 13 and 24. Minor, but noticeable differences between the surface microlayer and surface waters were detectable at Stations EGY and STB17, owing to the presence of two distinct ribotypes in the surface microlayer. At Station HNL, a few minor ribotypes distinguished the CE-SSCP profile from the surface microlayer to that of surface waters.

At Stations MAR, GYR and STB17 we compared the relative contribution of major bacterial groups in the surface microlayer and surface waters, using in situ hybridization. The percent DAPI-stained cells identified by a combination of the 
Table 2. Concentration of particulate organic carbon (POC) and nitrogen (PON), dissolved organic carbon (DOC) and chromophoric dissolved organic matter (cDOM) in the sea surface microlayer (SML) and in surface waters (SW). n.d. - not determined.

\begin{tabular}{llllllll}
\hline & & MAR & HNL & STB3 & GYR-2 & EGY & STB17 \\
\hline \multirow{2}{*}{ POC $(\mu \mathrm{M})$} & SML & 10.3 & 11.5 & 14.8 & 7.3 & 25.7 & 23.0 \\
& SW & 5.4 & 8.8 & 4.0 & 2.8 & 3.4 & 4.7 \\
PON $(\mu \mathrm{M})$ & SML & 1.0 & 1.0 & 1.2 & 0.5 & 4.2 & 2.8 \\
& SW & 0.7 & 1.0 & 0.5 & 0.3 & 0.6 & 0.8 \\
POC:PON & SML & 10.8 & 11.5 & 12.7 & 14.6 & 6.2 & 8.3 \\
& SW & 7.6 & 8.5 & 7.9 & 8.4 & 5.2 & 6.0 \\
DOC $(\mu \mathrm{M})$ & SML & 80 & 85 & 94 & 81 & 105 & 88 \\
& SW & 85 & 92 & 88 & 78 & 99 & 88 \\
$\operatorname{cDOM}\left(\mathrm{Abs}_{\left.350 \mathrm{~nm}^{-1}\right)} \mathrm{m}^{-1}\right)$ & SML & 0.072 & 0.097 & 0.051 & 0.036 & 0.073 & n.d. \\
& SW & 0.037 & 0.050 & 0.027 & 0.016 & 0.014 & n.d. \\
\hline
\end{tabular}

Table 3. Concentrations of chlorophyll- $a(\operatorname{chl}-a), b(\operatorname{chl}-b), c(\operatorname{chl}-c)$ and Divinyl chl $a$ in the sea surface microlayer (SML) and surface waters (SW). BD - below limit of detection.

\begin{tabular}{lllllll}
\hline & & MAR & HNL & GYR-4 & EGY & STB17 \\
\hline \multirow{2}{*}{$\operatorname{chl}-a\left(\mu \mathrm{g} \mathrm{l}^{-1}\right)$} & SML & 0.201 & 0.075 & 0.013 & 0.095 & 0.12 \\
& SW & 0.168 & 0.128 & 0.021 & 0.064 & 0.11 \\
$\operatorname{chl}-b\left(\mu \mathrm{g} \mathrm{l^{-1 }}\right)$ & SML & 0.017 & 0.011 & 0.001 & 0.011 & 0.124 \\
& SW & 0.017 & 0.020 & 0.001 & 0.004 & 0.110 \\
$\operatorname{chl}-c\left(\mu \mathrm{g} 1^{-1}\right)$ & SML & 0.047 & 0.003 & 0.001 & 0.015 & 0.024 \\
\multirow{3}{*}{ Divinyl chl- $a\left(\mu \mathrm{gl}^{-1}\right)$} & SW & 0.033 & 0.016 & 0.002 & 0.008 & 0.023 \\
& SWL & 0.048 & 0.042 & 0.003 & 0.010 & BD \\
& SW & 0.027 & 0.049 & 0.004 & 0.008 & BD \\
\hline
\end{tabular}

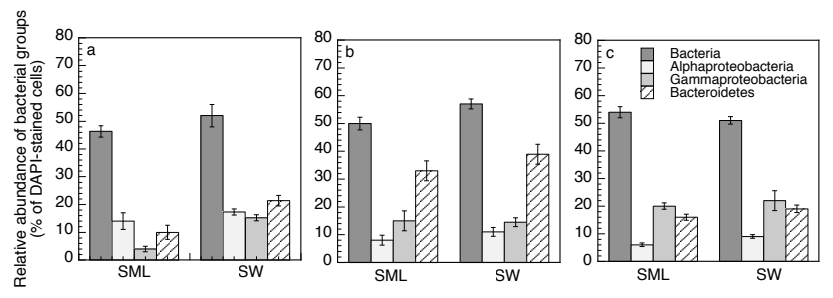

Fig. 5. Relative contribution of Bacteria and major bacterial groups to total DAPI-stained cells in the surface microlayer (SML) and in surface waters (SW) at Stations MAR (a), GYR (b) and STB17 (c). The control probe NON was on average $2 \%$ of DAPI-stained cells. Mean values $\pm \mathrm{SE}$ are given.

three probes EUB338I, EUB338II and EUB338III varied between $46-54 \%$ and $51-65 \%$ in the surface microlayer and in surface waters, respectively (Fig. 5). Our detection rate of Bacteria is in the lower range of values reported in the literature, and it is also lower than those we observed in the coastal and off-shore Mediterranean Sea and in the Southern Ocean (70-90\%, unpublished data). The low metabolic activity and the small size of bacterial cells, and possibly also an inef- ficient cell-wall permeabilization could account for the low detection rate observed in the present study.

The slightly lower percentage of DAPI-stained cells identified as Bacteria in the surface microlayer probably reflects the lower heterotrophic bacterial activity in this layer as compared to surface waters (see below). The sum of the relative contributions of Alpha-, and Gammaproteobacteria and Bacteroidetes amounted to $82 \pm 20 \%$ (mean \pm SD, $n=3$ ) in the surface microlayer and equaled (mean $\pm \mathrm{SD}, 100 \pm 10 \%)$ the percent EUB positive cells in surface waters. Overall, no differences in the relative contribution of the major bacterial groups were detectable between the surface microlayer and surface waters (Fig. 5). At Station MAR, Alpha-, and Gammaproteobacteria and Bacteroidetes had similar relative contributions in both layers. At Station GYR Bacteroidetes were the dominant phylogenetic group (33 to 39\% of DAPIstained cells), and at STB17 Bacteroidetes (16 to $19 \%$ of DAPI-stained cells) and Gammaproteobacteria (20 to $22 \%$ of DAPI-stained cells) dominated in terms of abundance the heterotrophic bacterial community. 
Table 4. Abundance of the major components of the microbial community in the sea surface microlayer (SML) and surface waters (SW). n.d. - not determined; b.d. - below limit of detection. * - data are based on flow cytometric analysis; ** - data are based on microscopic observations.

\begin{tabular}{lllllllll}
\hline & & MAR & HNL & STB3 & GYR-2 & GYR-4 & EGY & STB17 \\
\hline \multirow{2}{*}{ Synechococcus spp.* $\left(\times 10^{7} 1^{-1}\right)$} & SML & 5.8 & 1.2 & 0.3 & 0.1 & 0.02 & 0.7 & 0.2 \\
Pico/Nanoeukaryotes* $\left(\times 10^{6} 1^{-1}\right)$ & SW & 4.9 & 1.4 & 0.3 & 0.1 & 0.04 & 0.5 & 0.2 \\
& SML & 3.9 & 5.1 & 0.8 & 0.5 & 0.4 & 3.0 & 3.9 \\
Plastidic Nanoflagellates** $\left(\times 10^{5} 1^{-1}\right)$ & SW & 3.6 & 5.7 & 1.4 & 0.6 & 0.4 & 2.6 & 3.7 \\
& SML & 19.9 & 21.5 & 5.3 & 0.4 & 0.4 & n.d. & n.d. \\
Heterotrophic bacteria* $\left(\times 10^{8} 1^{-1}\right)$ & SW & 16.6 & 22.2 & 3.5 & 0.1 & 0.6 & n.d. & n.d. \\
& SML & 9.6 & 8.9 & 6.5 & 3.8 & 3.6 & 9.0 & 8.4 \\
Heterotrophic nanoflagellates** $\left(\times 10^{5} 1^{-1}\right)$ & SW & 9.4 & 8.7 & 6.1 & 3.7 & 3.5 & 7.0 & 7.8 \\
& SWL & 7.6 & 5.4 & 1.1 & 1.8 & 2.4 & n.d. & n.d. \\
\hline
\end{tabular}

3.4 Contribution of major bacterial groups to bulk leucine incorporation

By contrast to the heterotrophic bacterial abundance, distinct differences in bacterial heterotrophic production, as determined by ${ }^{3} \mathrm{H}$-leucine incorporation, were detectable between the two layers. Bacterial leucine incorporation in the surface microlayer accounted for $5 \%$ to $80 \%(n=6)$ of that at $5 \mathrm{~m}$ and the inhibition of bacterial heterotrophic production in the surface microlayer was most pronounced at low wind speeds (Fig. 6). An exception to this pattern was Station $\mathrm{HNL}$, where leucine incorporation in the surface microlayer was enhanced by $20 \%$ as compared to surface waters. Only a small fraction of DAPI-stained cells incorporated leucine in the surface microlayer (4-13\%) in comparison to surface waters (19-33\%), further indicating the inhibition of the bacterial activity in the surface microlayer.

Different bacterial groups were responsible for bulk leucine incorporation in the surface microlayer as compared to surface waters at Stations GYR and STB17 (Fig. 7). At Station GYR, Bacteroidetes clearly dominated leucine uptake in the surface microlayer (43\% of DAPI-stained cells associated with silver grains), while in surface waters both $\mathrm{Al}$ phaproteobacteria and Bacteroidetes (26\% and 36\%, respectively, of DAPI-stained cells associated with silver grains) had similar contributions to leucine uptake. At Station STB17, Gammaproteobacteria and Bacteroidetes dominated leucine uptake in the surface microlayer $(28 \%$ and $25 \%$ respectively, of DAPI-stained cells associated with silver grains), while the three bacterial groups studied contributed equally to leucine uptake in surface waters (13\% to $16 \%$ of DAPI-stained cells associated with silver grains) (Fig. 7).

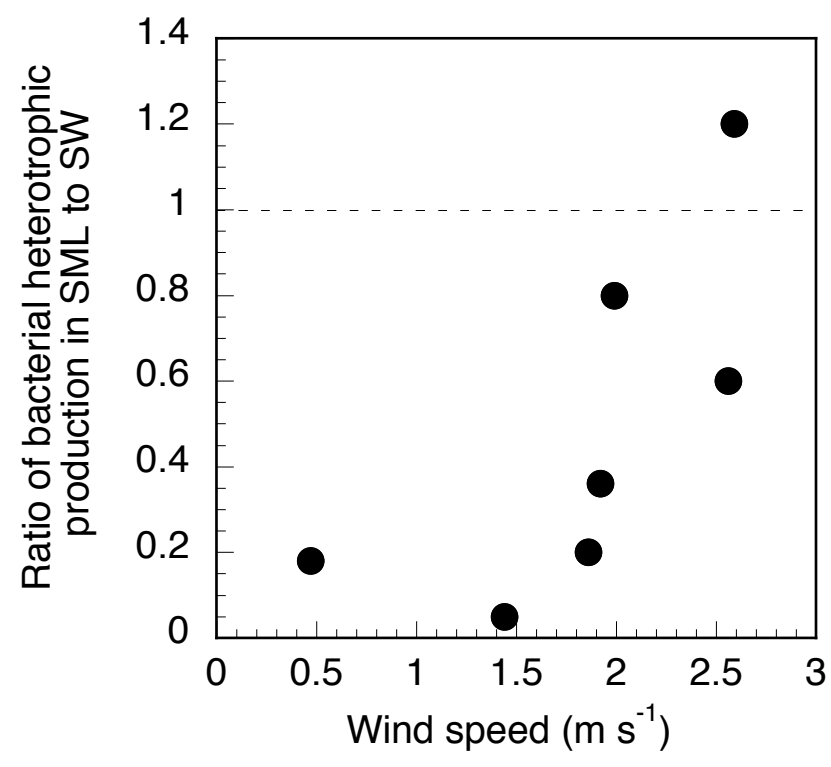

Fig. 6. Relation between the ratio of bacterial heterotrophic production in the surface microlayer (SML) to surface waters (SW) and the mean wind speed $6 \mathrm{~h}$ prior to sampling.

\section{Discussion}

The thickness of the surface microlayer sampled, and thus its definition for a given study, depends on the sampling device applied. The metal screen we used in the present study collects the upper 250-440 $\mu \mathrm{m}$ water layer (Garrett 1965), while the layers collected by the glass plate (Harvey and Burzell 1972) and the rotating drum (Harvey 1966) are thinner $(60-100 \mu \mathrm{m})$. For specific microbiological studies membranes are used to collect the upper 1 to $40 \mu \mathrm{m}$ (Kjelleberg et al., 1979). These differences are mainly due to the physical mechanisms to sample the uppermost layer of aquatic systems, with some devices being more selective than oth- 


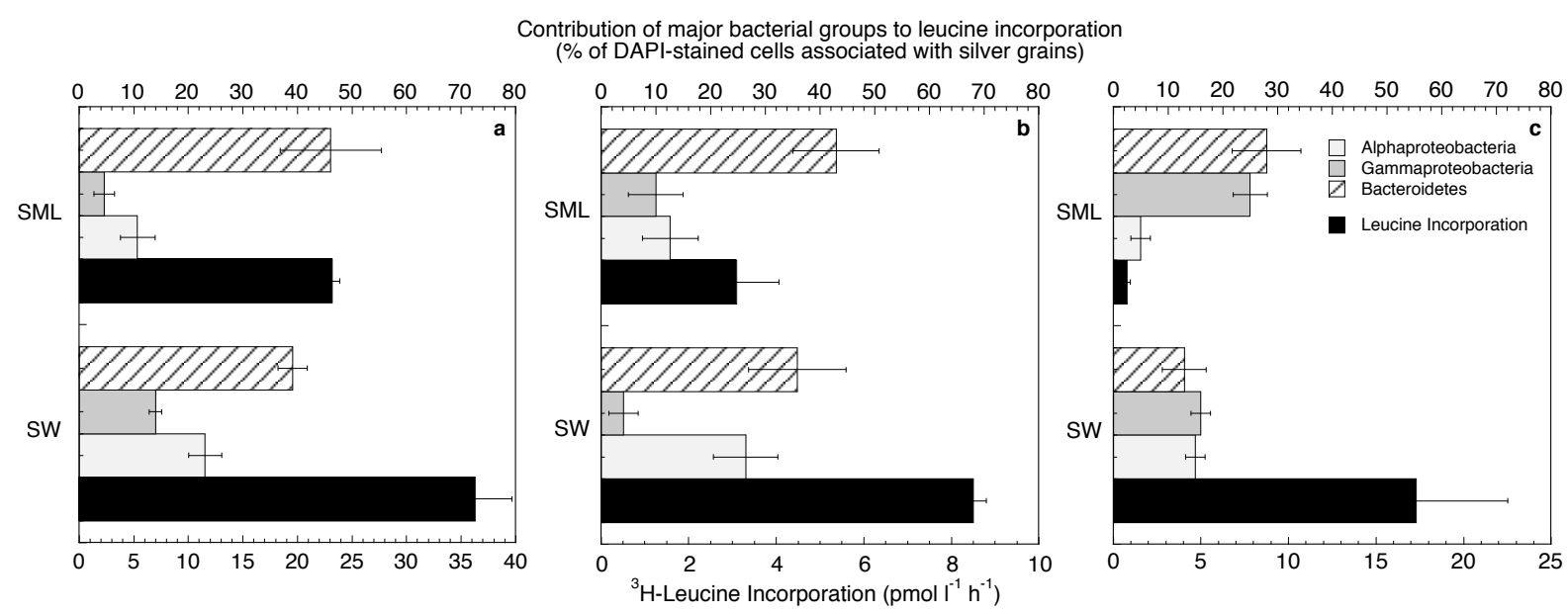

Fig. 7. Bulk ${ }^{3} \mathrm{H}$-leucine incorporation and relative contribution of bacterial groups to leucine-incorporation in the surface microlayer (SML) and in surface waters (SW) at Stations MAR (a), GYR (b) and STB17 (c). For ${ }^{3} \mathrm{H}$-leucine incorporation, mean values \pm variation of duplicate incubations, and for the relative contribution of bacterial groups mean values $\pm \mathrm{SE}$ are given.

ers. Based on a large data set of chemical (Momzikoff et al., 2004) and biological (Agogué et al., 2004) parameters collected both with the metal screen and the glass plate in the coastal Mediterranean Sea, no significant differences in the enrichment factors between the two samplers were observed. Kuznetsova et al. (2004) report a more efficient collection of surface microlayer dissolved and particulate material by the screen than by the drum, despite the thinner layer sampled by the latter. These studies demonstrate that the collection of the surface microlayer to study the parameters considered herein are most likely not biased due to dilution with surface waters, despite the larger thickness of the layer sampled. Our choice of the screen sampler is driven by the efficient, non-selective sampling of a relatively large water volume for chemical and biological analyses.

The marked accumulation of particulate organic matter at the sea surface observed in the present study was not accompanied by any pronounced enrichment in photo- or heterotrophic organisms. This suggests that detrital particles, including colloidal aggregates, transparent exopolymeric particles (TEP), and submicron particles most likely constitute an important fraction of the surface microlayer biofilm. The higher $\mathrm{C}: \mathrm{N}$ ratios of particulate organic matter observed in the present and previous studies (Nishizawa, 1971; Taguchi and Nakajima, 1971) further support this notion. The enrichment in particulate organic matter was strongly controlled by wind history, but independent of particulate organic matter concentrations in surface waters, suggesting that physical processes, such as turbulent mixing, transport by rising bubbles or buoyant particles were important for the surface microlayer formation. The most pronounced accumulation of particulate organic matter was observed at Station EGY where calm wind conditions $\left(\leq 2 \mathrm{~m} \mathrm{~s}^{-1}\right)$ prevailed over roughly $18 \mathrm{~h}$ prior to surface microlayer collection. It was interesting to note that at this site the $\mathrm{C}: \mathrm{N}$ ratio of particulate organic matter in the surface microlayer was similar to that in surface waters (Table 2). Station EGY was the only site where a pronounced enrichment in cell abundance and biomass of autotrophic and heterotrophic organisms was observed (Tables 3 and 4). These observations could indicate the transport of fresh material to the ocean surface, but they could also reflect photo- and heterotrophic biomass production in the surface microlayer when calm wind conditions exist over an extended time period. The latter idea is, however, not supported by results from the present study, as the inhibition in bacterial heterotrophic production in the surface microlayer was most pronounced at calm sea conditions (Fig. 6). This suggests that wind-induced physical processes determine not only the amount, but to some extent also the characteristics of the particulate organic matter that accumulates at the air-water interface.

The chemical characteristics of surface microlayer dissolved organic matter (DOM) appear to contrast the observations on particulate organic matter. Recent studies performed in the open Atlantic and the western Mediterranean Sea report a pronounced enrichment in dissolved free amino acids and a substantially lower C:N ratio in the DOM from the surface microlayer as compared to that from surface waters (Kuznetsova et al., 2004; Reinthaler et al., 2008). Interestingly, Reinthaler et al. (2008) concluded that the bioreactivity of the surface microlayer DOM was low, despite the high contribution of amino acids to DOC and DON. Selective accumulation, and also in situ production were both suggested to account for the enrichment in amino acids in the surface microlayer (Kuznetsova et al., 2004; Reinthaler et al., 2008). The consistently higher concentrations of chromophoric DOM (cDOM) in the surface microlayer observed in the present and previous studies (Carlson, 1983) are 
clearly indicative for the selective accumulation of DOM at the air-water interface. Removal of cDOM by photomineralization and photobleaching is most likely rapid in the surface microlayer, the observation that $\mathrm{CDOM}$ is consistently enriched strongly suggests the continuous supply from bulk seawater by selective scavenging.

In the present study, bacterial heterotrophic production was clearly reduced in the surface microlayer as compared to surface waters. Previous studies support (Sieburth et al., 1976; Carlucci et al., 1986) or contrast (Dietz et al., 1976; Bell and Albright, 1982; Bailey et al., 1983; Williams et al., 1986; Agogué et al., 2004; Reinthaler et al., 2008) this observation. A more consistent pattern among studies is observed on rates of bacterial ( $<0.8 \mu \mathrm{m}$ fraction) or microbial community respiration in the surface microlayer, generally exceeding those in surface waters by several-fold (Garabétian 1990; Obernosterer et al., 2005; Reinthaler et al., 2008). These contrasting responses most likely reflect the different characteristics of the surface microlayer. The enrichment in organic and inorganic matter renders the surface microlayer a potentially favorable habitat for heterotrophic bacteria, at the same time it is exposed to drastic changes in temperature, $\mathrm{pH}$, salinity and also to high intensities of solar radiation, in particular ultraviolet radiation. Based on the short incubation time, bacterial heterotrophic production provides an instantaneous response to the conditions in the surface microlayer. By contrast, respiration measurements require $12 \mathrm{~h}-24 \mathrm{~h}$ incubations in the dark and they more likely reflect the potential of organic matter originating from the surface microlayer in sustaining bacterial metabolism.

Bacterial growth rates could further indicate the activity of the bacterial community in the surface microlayer. Bacterial growth rates are commonly calculated on the basis of total bacterial cell abundance even though several independent approaches have shown that only a fraction of the bacterial community can be considered active (Gasol et al., 1999; Lebaron et al., 2001, Zubkov et al., 2001). The microautoradiographic observations performed in the present study allowed us to estimate the fraction of active cells, accounting for roughly $10 \%$ and $25 \%$ of DAPI-stained cells in the surface microlayer and surface waters, respectively. Assuming that this percentage represents the active part of the bacterial community, growth rates in the surface microlayer $\left(0.6 \mathrm{~d}^{-1}\right)$ exceeded those in surface waters $\left(0.3 \mathrm{~d}^{-1}\right)$ by a factor of two. Could this indicate that only a few bacterial groups are active in the surface microlayer accounting for most of the bacterial heterotrophic production in this particular environment?

Our results from the fingerprints and the in situ hybridization suggest that the surface microlayer is not inhabited by a particular bacterioneuston community. Two complementary approaches, a PCR-based (i.e. CE-SSCP) and a PCRindependent method (i.e. CARD-FISH) support this notion. The overall close similarity of the CE-SSCP fingerprints, each represented by 13-24 ribotypes, indicate that the bacterial community structure in the surface microlayer strongly resembles that in surface waters. Even though the probes we used in the present study provide information on a low phylogenetic level, the results from the in situ hybridization appear to support this conclusion. Given the low bacterial growth rates determined in the present study, and the relatively short time period over which the surface microlayer persists, an in situ development of a specific bacterioneuston community is unlikely. Physical processes are mainly responsible for the formation of the surface microlayer, with upward transport of particulate material being a predominant process. The differences that we observed in the fingerprints between the two layers is most likely owing to the selective enrichment of the surface microlayer by specific ribotypes. Likely candidates are bacteria attached to particles that are transported to the air-sea interface. The structure of the bacterial community attached to particles in the water column differs from that of free-living bacteria (Acinas et al., 1999; Riemann and Winding, 2001; Ghiglione et al., 2007) and Bacteroidetes were found to have an important contribution to the bacterial communities associated with aggregates (DeLong et al., 1993; Ploug et al., 1999; Simon et al., 2002). Marine aerosol particles have also been observed to be enriched in bacteria, and their transport in the atmosphere has been suggested a potentially important dispersal mechanism (Aller et al., 2005).

Our conclusion on the close similarity between the bacterial community structure in the surface microlayer and surface waters is supported by results from samples collected in the same way from the coastal Mediterranean Sea (Agogué et al., 2004), but they contrast the conclusion of a study conducted in the coastal North Sea (Franklin et al., 2005). These authors utilized hydrophilic membranes to collect surface microlayer bacteria, and based on 16S rRNA clone libraries they observed a lower bacterial diversity in the surface microlayer as compared to surface waters (Franklin et al., 2005). The potentially selective adsorption of bacteria onto hydrophilic membranes as discussed in Agogué et al. (2004), could at least partly account for the different conclusions obtained by these studies.

In contrast to the similarity between the two layers in terms of community structure and abundance of major bacterial groups, differences in the composition of the active community were detectable. This was particularly pronounced at Station STB17 where Bacteroidetes and Gammaproteobacteria dominated the active community in the surface microlayer, while the three bacterial groups investigated contributed equally to the active community in surface waters (Fig. 7). Even though these bacterial groups contain each a diverse assemblage of sub-groups, they have been attributed specific characteristics, based on different experimental approaches. There is for instance increasing evidence that members of the Bacteroidetes group play an important role in the degradation of complex polymeric substances (Cottrell and Kirchman, 2000; Kirchman 2002; Cottrell et al., 2005). Several members belonging to the planktonic heterotrophic Gammaproteobacteria were characterized as 
"opportunistic" due to their ability to rapidly respond to nutrient enrichment (Pinhassi and Berman, 2003). Pronounced growth of Gammaproteobacteria was detectable in nitrogenamended incubations at Station GYR (Van Wambeke et al., personal communication). The dominance of Bacteroidetes and Gammaproteobacteria in the active community in the surface microlayer could reflect the rapid response of members of these bacterial groups to changes in the growth conditions, such as the enrichment and composition of organic and inorganic matter. These results suggest that even short time periods in the surface microlayer result in differences in bacterial groups accounting for leucine incorporation, probably as a response to the differences in the physical and chemical nature of the two layers.

In the open ocean, the organic matter accumulating at the air-sea interface originates predominantly from phytoplankton primary production. The vertical flux of phytoplanktonderived organic carbon to the ocean surface has, to the best of our knowledge, never been evaluated. The potential importance of an upward flux of organic matter has been illustrated by studies on buoyant particles. TEP-rich microaggregates, for example, have been reported to ascend at velocities as fast as $0.1-1 \mathrm{~m} \mathrm{~d}^{-1}$ to the ocean surface (Azetsu-Scott and Passow, 2004). The accumulation of organic matter at the sea surface impacts its physical structure and consequently the gas transfer rates. Photochemical mineralization of surface microlayer organic matter could have important consequences for the air-sea gas exchange (Obernosterer et al., 2005). The results from the present study suggest that heterotrophic bacteria in the surface microlayer do not represent an assemblage specific to this environment. The strong inhibition of bacterial biomass production in the surface microlayer indicates a lack of adaptation of the bacterial community, most likely due to its short residence time. This could lead to the conclusion that heterotrophic bacteria do not have a major contribution to the degradation of surface microlayer organic matter. This idea, however, contrasts the conclusion drawn from bacterial and community respiration rates based on bottle incubation experiments (Calleja et al., 2005; Obernosterer et al., 2005; Reinthaler et al., 2008). To better understand and determine the importance of biological processes for the air-sea exchange, clearly novel techniques allowing in situ measurements of biological fluxes at the air-water interface are required.

Acknowledgements. We are greatful to S. Blain, D. Marie and A. Sciandra for their help with the surfae microlayer sampling. We thank the chief scientists H. Claustre and A. Sciandra, and the captain and the crew of the $R / V$ Atalante for their support aboard. D. Taillez kindly provided the wind speed data. Two anonymous reviewers helped improve an earlier version of the manuscript. Financial support for this work came from the French National program PROOF (INSU/CNRS).

Edited by: A. Boetius

\section{References}

Acinas, S. G., Anton, J., and Rodriguez-Valera, F.: Diversity of free-living and attached bacteria in offshore Mediterranean waters as depicted by analysis of genes encoding 16S rRNA, Appl Environ. Microbiol., 65, 514-522, 1999.

Agogué, H., Casamayor, E. O., Joux, F., Obernosterer, I., Dupuy, C., Lantoine, F., Catala, P., Weinbauer, M. G., Reinthaler, T., Herndl, G. J., and Lebaron, P.: Comparison of samplers for the biological characterization of the sea surface microlayer, Limnol. Oceanogr. Methods, 2, 213-225, 2004.

Aller, J. Y., Kuznetsova, M. R., Jahns, C. J., and Kemp, P. F.: The sea surface microlayer as a source of viral and bacterial enrichment in marine aerosols, Aerosol Science, 36, 801-812, 2005.

Azetsu-Scott, K. and Passow, U.: Ascending marine particles: Significance of transparent exopolymer particles (TEP) in the upper ocean, Limnol. Oceanogr., 49, 741-748, 2004.

Bailey, C. A., Neihof, R. A., and Tabor, P. S.: Inhibitory effect of solar radiation on amino acid uptake in Chesapeake Bay bacteria, Appl. Environ. Microbiol., 46, 44-49, 1983.

Bell, C. R. and Albright, L. J.: Bacteriological investigation of the neuston and plankton in the Fraser River estuary, British Columbia., Estuar. Coast. Shelf Sciences, 15, 385-394, 1982.

Benner, R. and Strom, M.: A critical evaluation of the analytical blank associated with DOC measurements by high- temperature catalytic oxidation, Mar. Chem., 41, 153-160, 1993.

Brosius, J., Dull, T., Sleeter, D. D., and Noller, H. F.: Gene organization and primary structure of a ribosomal RNA operon from Escherichia coli, J. Molecular Biology, 148, 107-127, 1981.

Calleja, M. L., Duarte, C. M., Navarro, N., and Agusti, S.: Control of air-sea $\mathrm{CO}_{2}$ disequilibria in the subtropical NE Atlantic by planktonic metabolism under the ocean skin, Geophys. Res. Lett., 32, 2005.

Carlson, D. J.: Dissolved organic materials in surface microlayers: Temporal and spatial variability and relation to sea state, Limnol. Oceanogr., 28, 415-431, 1983.

Carlucci, A. F., Craven, D. B., Robertson, K. J., and Williams, P. M.: Surface-film microbial populations: diel amino acid metabolism, carbon utilization, and growth rates, Mar. Biol., 92, 289-297, 1986.

Cottrell, M. T. and Kirchman, D. L.: Natural assemblages of marine proteobacteria and members of the Cytophaga-Flavobacter cluster consuming low-and high-molecular-weight dissolved organic matter, Appl. Environm. Microbiol., 66, 1692-1697, 2000.

Cottrell, M. T. and Kirchman, D. L.: Contribution of major bacterial groups to bacterial biomass production (thymidine and leucine incorporation) in the Delaware estuary, Limnol. Oceanogr., 48, 168-178, 2003.

Cottrell, M. T., Yu, L., and Kirchman, D. L.: Sequence and expression analyses of Cytophaga-like hydrolases in a Western arctic metagenomic library and the Sargasso Sea, Appl Environ Microbiol, 71, 8506-8513, 2005.

Delbès, C., Moletta, R., and Godon, J.: Monitoring of activity dynamics of an aerobic digester bacterial community using $16 \mathrm{~S}$ rRNA polymerase chain reaction-single-strand conformation polymorphism analysis, Environ Microbiol, 2, 506-515, 2000.

DeLong, E. F., Franks, D. G., and Alldredge, A. L.: Phylogenetic diversity of aggregate-attached vs. free-living marine bacterial assemblages, Limnol. Oceanogr., 38, 924-934, 1993. 
Dietz, A. S., Albright, L. J., and Tuominen, T.: Heterotrophic activities of bacterioneuston and bacterioplankton, Can. J. Microbiol., 22, 1699-1709, 1976.

Franklin, M. P., McDonald, I. R., Bourne, D. G., Owens, N. J. P., Upstill-Goddard, R. C., and Murrell, J. C.: Bacterial diversity in the bacterioneuston (sea surface microlayer): the bacterioneuston through the looking glass, Environ Microbiol, 7, 723736, 2005

Frew, N. M.: The role of organic films in air-sea gas exchange, 121172, in: The sea surface and global change, edited by: Liss, P. S. and Duce, R. A., Cambridge University Press, 1997.

Fukuda, R., Ogawa, H., Nagata, T., and Koike, I.: Direct determination of carbon and nitrogen contents of natural bacterial assemblages in marine environments, Appl. Environ. Microbiol., 64, 3352-3358, 1998.

Garabétian, F.: Production de $\mathrm{CO}_{2}$ à l'interface air-mer, Une approche par l'étude des phénomènes respiratoires dans la microcouche de surface, Int Rev ges Hydrobiol, 76, 219-229, 1990.

Garrett, W. D.: Collection of slick-forming materials from the sea surface, Limnol. Oceanogr., 10, 602-605, 1965.

Gasol, J. M., Zweifel, U. L., Peters, F., Fuhrman, J. A., and Hagström, A.: Significance of size and nucleic acid content heterogeneity as measured by flow cytometry in natural planktonic bacteria, Appl. Environ. Microbiol., 65, 4475-4483, 1999.

Ghiglione, J.-F., Larcher, M., and Lebaron, P.: Spatial and tempral scales of variation in the bacterioplankton community structure in the NW Mediterranean Sea, Aquat. Microb. Ecol., 40, 229240, 2005.

Ghiglione, J.-F., Mevel, G., Pujo-Pay, M., Mousseau, L., Lebaron, P., and Goutx, M.: Diel and seasonal variations in abundance, activity, and community structure of particle-attached and freeliving bacteria in NW Mediterranean Sea, Microb Ecol, 54, 217 231, 2007.

Harvey, G. W.: Microlayer collection from the sea surface: a new method and initial results, Limnol. Oceanogr., 11, 608-614, 1966.

Harvey, G. W. and Burzell, L. A.: A simple microlayer method for small samples, Limnol. Oceanogr., 17, 156-157, 1972.

Joux, F., Agogué, H., Obernosterer, I., Dupuy, C., Reinthaler, T., Herndl, G. J., and Lebaron, P.: Microbial community structure in the sea surface microlayer at two contrasting coastal sites in the northwestern Mediterranean Sea, Aquat. Microb. Ecol., 42, 91-104, 2006.

Kirchman, D. L.: The ecology of Cytophaga-Flavobacteria in aquatic environments, FEMS Microbiology Ecology, 39, 91, 2002.

Kjelleberg, S., Stenström, T. A., and Odham, G.: Comparative study of different hydrophobic devices for sampling lipid surface films and adherent microorganisms, Mar. Chem., 53, 21-25, 1979.

Kuznetsova, M., Lee, C., Aller, J., and Frew, N.: Enrichment of amino acids in the sea surface microlayer at coastal and open ocean sites in the North Atlantic Ocean, Limnol. Oceanogr., 49, 1605-1619, 2004.

Lebaron, P., Servais, P., Agogue, H., Courties, C., and Joux, F.: Does the high nucleic acid content of individual bacterial cells allow us to discriminate between active cells and inactive cells in aquatic systems?, Appl. Environ. Microbiol., 67, 1775-1782, 2001.

Lee, D. H., Zo, Y. G., and Kim, S. J.: Non-radioactive method to study genetic profiles of natural bacterial communities by PCRsingle-strand-conformation polymorphism, Appl. Environ. Microbiol., 62, 3112-3120, 1996.

Liss, P. S., Watson, A. J., Bock, E. J., Jaehne, B., Asher, W. E., Frew, N. M., Hasse, L., Korenowski, G. M., Merlivat, L., Philips, L. F., Schluessel, P., and Woolf, D. K.: Physical processes in the microlayer and the air-sea exchange of trace gases, 1-33, in: The sea surface and global change, edited by: Liss, P. S. and Duce, R. A., Cambridge University Press, 1997.

Marie, D., Simon, N., Guillon, L., Partensky, F., and Vaulot, D.: Flow cytometry analysis of marine picoplankton, 421-454, in: Living Color: Protocols in flow cytometry and cell sorting, edited by: Maggio, D., Springer Verlag, 2000.

Momzikoff, A., Brinis, A., Dallot, S., Gondry, G., Saliot, A., and Lebaron, P.: Field study of the chemical characterization of the upper ocean surface using various samplers, Limnol. Oceanogr, Methods, 2, 374-386, 2004.

Nishizawa, S.: Concentration of organic and inorganic material in the surface skin at the Equator, $155^{\circ} \mathrm{W}$, Bull. Plankton Soc. Japan, 18, 42-44, 1971.

Obernosterer, I., Catala, P., Reinthaler, T., Herndl, G. J., and Lebaron, P.: Enhanced heterotrophic activity in the surface microlayer of the Mediterranean Sea, Aquat. Microb. Ecol., 39, 293-302, 2005.

Pernthaler, A., Pernthaler, J., and Ammann, R.: Fluorescence in situ hybridization and catalyzed reporter deposition for the identification of marine bacteria, Appl. Environ. Microbiol., 86, 30943101, 2002.

Pinhassi, J. and Berman, T.: Differential growth response of colonyforming Alpha-and Gammaproteobacteria in dilution culture and nutrient addition experiments from Lake Kinneret (Israel), the Eastern Mediterranean Sea, and the Gulf of Eilat, Appl. Environ. Microbiol., 69, 199-211, 2003.

Ploug, H., Grossart, H. P., Azam, F., and Joergensen, B. B.: Photosynthesis, respiration and carbon turnover in sinking marine snow from surface waters of Southern California Bight: implicatiosn for the carbon cycle in the ocean, Mar. Ecol. Prog. Ser. 179, 1-11, 1999.

Ras, J., Claustre, H., and Uitz, J.: Spatial variability of phytoplankton pigment distributions in the Subtropical South Pacific Ocean: comparison between in situ and modelled data, Biogeosciences, 5, 353-369, 2008, http://www.biogeosciences.net/5/353/2008/.

Reinthaler, T., Sintes, E., and Herndl, G. J.: Dissolved organic matter and bacterial production and respiration in the sea-surface microlayer of the open Atlantic and the western Mediterranean Sea, Limnol. Oceanogr., 53, 122-136, 2008.

Riemann, L. and Winding, A.: Community Dynamics of Free-living and Particle-associated Bacterial Assemblages during a Freshwater Phytoplankton Bloom, Microb. Ecol., 42, 274-285, 2001.

Sekar, R., Pernthaler, A., Pernthaler, J., Warnecke, F., Posch, T., and Amann, R.: An improved protocol for quantification of freshwater Actinobacteria by fluorescence in situ hybridization, Appl. Environ. Microbiol., 69, 2928-2935, 2003.

Sherr, E. B., Caron, D. A., and Sherr, B. F.: Staining of heterotrophic protists for visualization via epifluorescence microscopy, 213-227, in: Handbook of methods for aquatic microbial ecology, edited by: Kemp, P. F., Sherr, B. F., Sherr, E. B., and Cole, J. J., Lewis Publishers, 1993. 
Sieburth, J. M. N., Willis, P.-J., Johnson, K. M., Burney, C. M., Lavoie, D. M., Hinga, K. R., Caron, D. A., French Iii, F. W., Johnson, P. W., and Davis, P. G.: Dissolved organic matter and heterotrophic microneuston in the surface microlayers of the North Atlantic, Science, 194, 1415-1418, 1976.

Simon, M., Grossart, H. P., Schweitzer, B., and Ploug, H.: Microbial ecology of organic aggregates in aquatic ecosystems, Aquat. Microb. Ecol., 28, 175-211, 2002.

Smith, D. C. and Azam, F.: A simple, economical method for measuring bacterial protein synthesis rates in sea water using ${ }^{3} \mathrm{H}$ Leucine, Mar. Microb. Food Webs., 6, 107-114, 1992.

Taguchi, S. and Nakajima, K.: Plankton and seston in the sea surface of three inlets of Japan, Bull. Plankton Soc., Japan, 18, 2036, 1971.

Van Heukelem, L. and Thomas, C. S.: Computer-assisted highperformance liquid chromatography method development with applications to the isolation and analysis of phytoplankton pigments, J. Chromatography A., 901, 31-49, 2001.

Van Wambeke, F., Christaki, U., Giannakourou, A., Moutin, T., and Souvemerzoglou, K.: Longitudinal and vertical trends of bacterial limitation by phosphorus and carbon in the Mediterranean Sea, Microb. Ecol., 43, 119-133, 2002.
Williams, P. M., Carlucci, A. F., Henrichs, S. M., Vleet, E. S. V., Horrigan, S. G., Reid, F. M. H., and Robertson, K. J.: Chemical and microbiological studies of sea-surface films in the southern gulf of California and off the west coast of Baja California, Mar. Chem., 19, 17-98, 1986.

Zaitsev, Y.: Neuston of seas and oceans, 371-382, in: The sea surface and global change, edited by: Liss, P. S. and Duce, R. A., Cambridge University Press, 1997.

Zemmelink, H. J., Houghton, L., Sievert, S. M., Frew, N. M., and Dacey, J. W. H.: Gradients in dimethylsulfide, dimethylsulfoniopropionate, dimethylsulfoxide, and bacteria near the sea surface, Mar. Ecol. Prog. Ser., 295, 33-42, 2005.

Zubkov, M. V., Fuchs, B. M., Burkhill, P. H., and Amann, R.: Comparison of cellular and biomass specific activities of dominant bacterioplankton groups in stratified waters of the Celtic Sea, Appl. Environ. Microbiol., 67, 5210-5218, 2001. 